\title{
Mathematics ATtitudes AND ACADEMIC SELF- CONCEPTS OF GiFTED ANd TALENTED STUdents
}

\author{
Yasemin Deringöl
}

\begin{abstract}
Since the first half of the $20^{\text {th }}$ century, countries have begun to accelerate the education of gifted individuals in sports/arts and science and mathematics as a way of proving their superiority, and enabled these individuals to demonstrate their talents. There is a limited number of studies that measure the mathematics attitudes and academic self-states of gifted and talented students, which are cognitive domain characteristics as well as affective domain characteristics. In this context, the main purpose of this study is to reveal the mathematical attitudes and academic self-states of gifted and talented students. The "Mathematics Attitude Scale" developed by Baykul (1990) and the "Academic Self-Concept Scale" adapted to Turkish by Senemoğlu (1989) were used to measure mathematics attitudes and academic self-concepts of students who were identified as gifted and talented. The students' mathematics attitude and academic self-scores were found to be high.
\end{abstract}

Key words: Gifted and Talented Student, Mathematics Attitude, Concept of Academic Self

\section{Introduction}

Learning occurs in cognitive, emotional and psychomotor domains. Therefore, the personal and environmental factors affecting learning impact all these three domains. Many studies to date have focused on the factors that affect cognitive learning. Therefore, studies on affective and psychomotor domains are rare (Çakır, Şahin, \& Şahin, 2000). However, it is known that these three domains influence each other and the behavioral changes take place in all three domains. For all these reasons, the affective domain has recently been regarded as a part of education as well as a focal point of research (Weinburg, 1995). Affective characteristics are "positive attitude towards mathematics, appreciation of its value, interest, motivation, anxiety about mathematics, and self-confidence features" (Baykul, 1992). Their attitudes play in important role when students fail or succeed in mathematics, or simply like it or not (Çoban, 1989). It is seen that the students with high mathematics achievement are more influenced by the attitude, method, teacher, family and environment factors than those with low mathematics achievement. Moreover, it is also found that the students who develop a positive attitude towards mathematics are more successful (Yenilmez \& Duman, 2008).

Another affective variable that has a guiding influence on student behaviors is selfhood. The self concept emphasizes that the individual feels him/herself a worthy person, trusts in his/her capacity and values his/her differences. There are four dimensions of the self concept: academic, social, emotional, and physical (Özden, 2003). Piyanc1 (2007) defines the concept of academic self, one of the dimensions of the self concept, as "an indicator of how the student perceives himself/herself in relation to other students in the school and in the classroom" and adds that it has the power to determine future success, in particular. Bloom (1998) defines the concept of academic self as "the level of belief and confidence of achieving success in a task that is academically oriented" (Erden \& Akman, 1998; Marsh, 1987; Marsh \& Craven, 2006). The power of academic self-concept in predicting success has been put forward as a measure of the highest affective characteristic (Bloom, 1998). Many studies 
show that there is a positive relationship between academic self-concept and achievement. According to these results, if the self-concepts of the students are positive, the achievements are high (Demirbass \& Yağbasan, 2007; Korkmaz \& Kaptan, 2002; Marsh \& O’Mara, 2008; Sanchez \& Roda, 2003). Just like every other course, academic self-concept is a factor that affects success in mathematics. The academic self-concept of mathematics is related to how confident that student is in performing well, learning new topics in mathematics, and getting good results in exams (Pehlivan \& Köseoğlu, 2011). At the same time, in various studies, it has been seen that the academic self-concepts of students are effective in determining their mathematics performances (Lopez, Lent, Brown, \& Gore, 1997; Marsh, Trautwein, Lüdtke, Köller, \& Baumert, 2006; Shavelson \& Bolus, 1982

When we look at the characteristics of gifted students in mathematics, they show certain gifted student characteristics in the academic field such as quick learning, sharp observation ability, strong questioning ability, extraordinary reasoning capacity and creativity. In addition, gifted students in mathematics use fluent, flexible, and creative ways to work with mathematical concepts (Sheffield, 2003) and tend to solve problems with flexible and creative solutions rather than using standard methods (Gavin, 2009; Miller, 1990; Mcclure \& Piggott, 2007; Souse, 2003). Gifted and talented students have a higher mathematics attitude compared to their normal peers (Zimmerman, Bandura, \& Martinez-Pons, 1992). However, they get bored in unsuitable educational environments, which negatively affects the attitudes of the students towards the lessons (Gentry, Gable, \& Springer, 2000). In order for the academic self-concept to be supported, it is necessary to meet the need of students for success and each student to have a suitable educational situation (Senemoğlu, 2010). The difficulty of the educational programs developed for them is apparent. It has been shown that Bloom's affective input characteristics (interest, attitude, academic self) in the Full Learning Model explain 25\% of the variance of academic achievement (Senemoğlu, 2010), and variables such as attitude, anxiety and academic self-perception were found in various studies to be the most important affective variables related to academic achievement (Valentine, DuBois, \& Cooper, 2004; Pehlivan \& Köseoğlu, 2010). In light of these, it becomes important to examine the affective factors such as mathematics attitudes and academic self-concepts of gifted and talented students in today's world where the majority of studies focus on the cognitive domain. In this study, it is aimed to examine the mathematics attitudes and academic self-concept status of gifted and talented students. For this purpose, the following questions were asked:

1. What are the students'mathematics attitudes and academic self-scores?

2. Does the students'mathematics attitude and academic self-scores differ significantly by gender?

3. Are there significant differences in the students'mathematics attitude and academic self-scores according to their grades?

4. Is there a significant relationship between students'mathematics attitude and academic selfconcept scores?

\section{Method}

\subsection{Research Design}

This research is a quantitative study of the mathematics attitudes and academic self-concepts of gifted and talented students, conducted with a screening model. The screening model aims to describe a past or present situation as it is (Karasar, 2005).

\subsection{Working Group}

The study sample consists of a total of 72 students (F: 42; M: 30) studying in Istanbul-Turkey selected by simple random sampling method and who were previously identified as gifted and talented students. The table showing the gender distribution of the sample according to grades is shown below. 
Table 1. Gender Distribution of Students based on Grades

\begin{tabular}{|c|c|c|c|}
\hline Grades & Genders & f & \% \\
\hline $3^{\text {rd }}$ Grade & Girl & 13 & 54.2 \\
\cline { 2 - 4 } & Boy & 11 & 45.8 \\
\cline { 2 - 4 } & Total & 24 & 100.0 \\
\hline \multirow{2}{*}{$4^{\text {th }}$ Grade } & Girl & 11 & 45.8 \\
\cline { 2 - 4 } & Boy & 13 & 54.2 \\
\cline { 2 - 4 } & Total & 24 & 100.0 \\
\hline \multirow{2}{*}{$5^{\text {th }}$ Grade } & Girl & 18 & 75.0 \\
\cline { 2 - 4 } & Boy & 6 & 25.0 \\
\cline { 2 - 4 } & Total & 24 & 100.0 \\
\hline
\end{tabular}

Thirteen (54.2\%) of the third grade students in the sample were female and $11(45.8 \%)$ were male; 11 of the fourth grade students $(45.8 \%)$ were female and $13(54.2 \%)$ were male; 18 (75\%) of the fifth grade students were female and $6(25 \%)$ were male.

\subsection{Data Collection Tools, Collecting Data and Data Analysis}

In this study, "Mathematics Attitude Scale" and "Academic Self-Concept Scale" were applied as a data collection tool to the students at the schools they were studying at.

Mathematics Attitude Scale: The "Mathematics Attitude Scale" developed by Baykul (1990) was used in order to determine students' attitudes towards mathematics. "Mathematics Attitude Scale" consisted of 30 Likert-type questions with the choices of 'I absolutely disagree', 'I do not agree', 'Undecided', 'I agree' and 'I absolutely agree'. 15 positive questions were scored as 1, 2, 3, 4, 5 and 15 negative questions were reversely scored as $5,4,3,2$, and 1 , respectively. The highest score that can be obtained from the Mathematics Attitude Scale is 150, and the lowest obtainable score is 30. The validity and reliability study of the scale was conducted by Baykul (1990), and the Cronbach's Alpha coefficient of the scale was found to be 0.96 . The reliability coefficient of the scale was calculated as 0.96 in this study.

Academic Self-Concept Scale: The "Academic Self-Concept Scale" developed by Brookover et al. (1964) and adapted to Turkish by Senemoğlu (1989) and consisting of 8 items was used to measure the academic self-concepts of students. The highest score that can be obtained from this scale is 40 , and the lowest score is 8 . The reliability of the scale was calculated as 0.91 for mathematics (Yanpar, 2005). The reliability coefficient for this study was 0.75 .

The statistical analyses of the data were made using SPSS 19.0, and Mann-Whitney U Test and Kruskal Wallis Test were used from nonparametric tests depending on the variables. The analysis of the relationship between mathematics attitude and academic self-concept was calculated by the Spearman Ranked Correlation Coefficient Technique.

\section{Findings and Comments}

This section contains the findings of the study. The findings of the first research question are presented in Table 2.

Table 2. Students 'Mathematics Attitude Scale and Academic Self-Concept Scale Scores

\begin{tabular}{|l|c|c|c|}
\hline \multicolumn{1}{|c|}{ Scales } & N & Mean & Std.D. \\
\hline Mathematics Attitude Scale & 72 & 117.25 & 28.31 \\
\cline { 2 - 4 } Academic Self-Concept Scale & 72 & 34.04 & 4.42 \\
\hline
\end{tabular}


As mentioned before, the highest score that can be obtained from the 30-item "Mathematics Attitude Scale" is 150 , and the lowest score is 30 . Based on these scores, it can be said that the mathematics attitude of the students were high. The highest score that can be obtained from the "Academic SelfConcept Scale" is 40, and the lowest score is 8. Again, based on these obtainable scores, it can be said that the academic self-concept scores of students were high.

Table 3. Mann-Whitney U Test Results of Mathematics Attitude Scale and Academic Self-Concept Scale Scores According to Gender

\begin{tabular}{|c|c|c|c|c|c|c|c|}
\hline Scales & Gender & $\mathbf{N}$ & $\begin{array}{l}\text { Mean } \\
\text { Rank }\end{array}$ & $\begin{array}{l}\text { Sum of } \\
\text { Ranks }\end{array}$ & $\mathbf{U}$ & $\mathbf{z}$ & $p$ \\
\hline \multirow[t]{2}{*}{ Mathematics Attitude Scale } & Girl & 42 & 31.68 & 1330.50 & \multirow[t]{2}{*}{427.500} & \multirow[t]{2}{*}{-2.314} & \multirow[t]{2}{*}{$.021 *$} \\
\hline & Boy & 30 & 43.25 & 1297.50 & & & \\
\hline \multirow{2}{*}{$\begin{array}{c}\text { Academic Self-Concept } \\
\text { Scale }\end{array}$} & Girl & 42 & 32.27 & 1355.50 & \multirow[t]{2}{*}{452.500} & \multirow[t]{2}{*}{-2.038} & \multirow[t]{2}{*}{$.042 *$} \\
\hline & Boy & 30 & 42.42 & 1272.50 & & & \\
\hline
\end{tabular}

There is a significant difference between the average "Mathematics Attitude Scale" $(U=427.500$, $p<.05)$ and "Academic Self-Concept Scale" $(\mathrm{U}=452.500 ; p<.05)$ scores of students according to gender. In other words, it was seen that gender affected mathematics attitude and academic selfconcepts of students. While the average mathematics attitude score of girls was 31.68 , that of boys was 43.25; and while the average academic self-concept score of girls was 32.27, that of boys was 42.42. Based on these results, the average scores of boys were higher than girls in both scales. In this context, mathematics attitudes and academic self-status of males were higher than females in the study sample (see Table 3).

Table 4: Kruskal Wallis Test Results of Mathematics Attitude Scale and Academic Self-Concept Scale Scores According to Grade

\begin{tabular}{|c|c|c|c|c|c|}
\hline Scales & Grades & $\mathbf{N}$ & Mean Rank & Chi-Square & $p$ \\
\hline \multirow{3}{*}{$\begin{array}{c}\text { Mathematics Attitude } \\
\text { Scale }\end{array}$} & $3^{\text {rd }}$ Grade & 24 & 37.75 & \multirow{3}{*}{.506} & \multirow{3}{*}{.77} \\
\hline & $4^{\text {th }}$ Grade & 24 & 37.73 & & \\
\hline & $5^{\text {th }}$ Grade & 24 & 34.02 & & \\
\hline \multirow{3}{*}{$\begin{array}{c}\text { Academic Self-Concept } \\
\text { Scale }\end{array}$} & $3^{\text {rd }}$ Grade & 24 & 38.19 & \multirow{3}{*}{.247} & \multirow{3}{*}{.88} \\
\hline & $4^{\text {th }}$ Grade & 24 & 35.35 & & \\
\hline & $5^{\text {th }}$ Grade & 24 & 35.96 & & \\
\hline
\end{tabular}

When we examined the mean scores of the "Mathematics Attitude Scale" and "Academic SelfConcept Scale" according to the grades of the students, no statistically significant difference was found. This result indicates that the grades of the students are not influencing students' mathematical attitudes and academic self-status (see Table 4).

Table 5. Spearman Rank Correlation Coefficient Analysis Results for the Relationship between "Mathematics Attitude Scale" and "Academic Self-Concept Scale"

\begin{tabular}{|c|c|c|c|}
\hline Scales & N & r & p \\
\hline $\begin{array}{c}\text { Mathematics Attitude Scale } \\
\text { Academic Self-Concept Scale }\end{array}$ & 72 & .568 & .000 \\
\hline
\end{tabular}

A statistically significant, moderate and positive correlation was found between the "Mathematics Attitude Scale" and "Academic Self-Concept Scale" total scores of the students $(\mathrm{r}=0.568, p<.01)$. 


\section{Conclusion}

In this study, in which mathematical attitudes and academic self-concepts of gifted and talented students were examined, it was found that both the mathematics attitudes and the academic selfconcepts of the students were high based on the scores that could be obtained from the scales. Yürük's (2003) study comparing the self-concepts of 132 gifted children and 146 normal children of the same age revealed that gifted children' s self-states were significantly higher than those of children with normal development. In order for the academic self-concept to be supported, it is necessary to meet the need of students for success and each student to have a suitable educational situation (Senemoğlu, 2010). Gifted and talented students in the study receive training together with their normal peers, but at the same time special training programs developed for them are also being implemented. Their high mathematics attitude and academic self-states may be a result of educational practices that meet their academic needs. Different results were found in studies that examined how their self-concepts evolved when gifted children were placed in a special environment. Karnes and Wherry (1981) found that general self concepts of gifted and talented students receiving special education were more positive than those in normal educational settings; Coleman and Fults (1982) found initial short-term declines following placement in special environments; Schneider et al. (1989) found that the academic selfperceptions of gifted students in special environments were lower than those in the normal education environment.

The results of the study showed that the mathematics attitudes of students differed according to gender. The data obtained showed that mathematics attitudes of male students were more positive than female students. The study of Hizlı (2013) also shows that the mathematics attitudes of gifted and talented male students are more positive than female students. Similar findings are found in a number of other studies (Hyde et, al. 1990; Hargreaves et, al, 2008; Kuloğlu \& Uzel, 2013; Pehlivan \& Köseoğlu, 2011). In addition, another finding obtained was that academic self-concepts differed according to gender. Our findings indicate that academic self-concept is higher in males. The high mathematics attitude and academic self-states of male students obtained in this study may have originated from the culture of the geography. The studies on this subject are also consistent with this finding (Dai, 2001; Piyanc1, 2007; Swiatek, 2000; Yürük, 2003).

Gifted and talented students'attitude towards mathematics and academic self-states did not differ significantly according to their grade level. The finding that attitude did not change according to grade level is supported by similar studies (Kalın, 2010; Metin \& Kangal, 2012; Pehlivan \& Köseoğlu, 2001; Sherman \& Christian 1999; Y1lmaz Atik, 2007), and the finding that academic self-concept did not change according to grade level is also supported by various studies (Metin \& Kangal, 2012; Sherman \& Christian 1999; Swiatek, 2000). One of the results of the study was that students' attitudes towards mathematics lessons and academic self-concept scores decreased, though not significantly. When the literature is examined, studies show that as the grade level increases, the attitudes of the students decrease (Hızlı, 2013; Pehlivan \& Köseoğlu, 2010; Swetman, 1991). There are also studies showing a decrease in academic self-concept scores in the early years of adolescence (Hendricks, 2002), and especially in middle school (B1yıkl1, 2014).

Based on our findings; there is a statistically significant, moderate and positive relationship between mathematics attitudes and academic self-states of gifted and talented students. In other words, the higher the mathematics attitudes of the students, the more likely it is that the idea of success in mathematics can be so positive. According to Bryıklı (2014), students with positive attitudes toward the lesson are successful, and at the same time begin to see themselves as academically sufficient. On the other hand, academic self-concept influences success, and the attitudes of students towards mathematics who see themselves as successful or unsuccessful also change. Based on various studies, it has been revealed that one of the most powerful variables in determining the attitudes towards the course is the academic self-concept (Çakır, Şahin, \& Şahin, 2000; George, 2000).

Just like all children, these children need families and especially teachers, who know that they have similar needs around them, and who understand that they require certain tools to meet these needs (Silverman, 1992). For the future of a country and all humanity, the education of gifted individuals is of utmost importance throughout the world. Providing equal educational opportunities to each 
individual is one of the fundamental principles of democracy as well as a fundamental human right. Equal educational opportunities do not mean the same educational opportunities, because gifted and talented students have different characteristics than their normal peers. For this reason, they need a differentiated education program (Enç, 2004; Çepni, Gökdere, \& Küçük, 2002; Davaslıgil \& Zeana, 2004; Kanl1, 2011; Tekbaş \& Ataman, 2004).

In light of all the issues discussed here, gifted individuals cannot sufficiently fulfill the high potential they have in situations where they cannot be adequately educated and trained. We see cases where individuals with a normal intelligence level amount to extraordinary achievements, while some gifted and talented individuals can barely be self-sufficient let alone coming up with great inventions. This shows us that we need a special education program for gifted individuals. Given the learning processes, it is understood that appropriate learning methods should also be used in the mathematics education of gifted students that allow them to be aware of their personal talents and enable them to improve their capacities and use that capacity at the highest level (Şenol, 2011). Comparisons made in different educational settings, such as special classes, accelerated and out-of-school programs, have shown that there are subtle differences in the self-concepts of gifted and talented students (Shechtman \& Silektor, 2012). In conclusion, it can be said that educational environments prepared according to the abilities and talents of gifted and talented students have positive effects on their cognitive and affective development.

\section{References}

[1] Baykul, Y. (1990). Changes in Attitudes towards Mathematics and Science Lessons from the Fifth Elementary School to the Last Classes of High Schools and Balanced Schools, Ankara: Ösym.

[2] Baykul, Y. (1992). Success in Mathematics, Hacettepe University Journal of Education, 87-95.

[3] Biylkl1, C. (2014). The Attidudes and Academic Self Concepts towards Turkish Course of Secondary Schools Students, Journal of Uludağ University of Faculty of Education, 27(1), 231254.

[4] Bloom, B. S. (1998). Human qualities and learning in school (Trans. Özçelik, D. A.), İstanbul: MEB.

[5] Coleman, J. M. \& Fults, B. A. (1982). Self concept and the gifted clasroom: The role of social comprarisons, Gifted Child Quaterly, 26, 116-120.

[6] Çakır, Ö.S., Şahin, T., \& Şahin, B. (2000). Predicting the effect of some variables related to 6. Grade science course on students'affective domains, Hacettepe University Journal of Education, 19, 43-49.

[7] Çepni, S., Gökdere, M., \& Küçük M. (2002). Sample event development based on the Purdue Model for gifted students in the field of science, V. National Science and Mathematics Education Congress, Ankara: ODTÜ.

[8] Çoban, A. (1989). Attitudes of Last Year Students in Ankara Central Secondary Schools on Mathematics, Unpublished Master Thesis, Gazi University, Ankara, Turkey.

[9] Dai, D. Y. (2001). A comparision of gender differences in academic self-concept and motivation between high-ability, Journal of Secondary Gifted Education, 13(1), 22-32.

[10] Davaslıgil, Ü. \& Zeane, M. (2004). Education of gifted students, I. Turkey Gifted Conference Proceedings, 42-50, Istanbul: Children's Foundation Publications.

[11] Demirbaş, M. \& Yağbasan, R. (2007). The Effect of Social Learning Theory on the Permanence of Academic Self-Concept Scores of $6^{\text {th }}$ Grade Elementary Students, Bilig, 43, 193-210.

[12] Enç, M. (2004). Reason for special education, I. Turkey Gifted Conference Proceedings, İstanbul: Children's Foundation Publications. 
[13] Erden, M. \& Akman, Y. (1998). Educational psychology (Development-Learning-Teaching), Ankara: Arkadaş Publications.

[14] Gavin, M. K. (2009). Mathematical talent, encylopedia of giftedness, creativty and talent, B. A. Kerr (Ed.) (Volume 1), Thousand Oaks, CA: Sage Publications.

[15] George, R. (2000). Measuring change in students'attitudes toward science over time: An application of latent variable growth modeling, Journal of Science Education and Technology, 9(3), 213-225.

[16] Gentry, M., Gable, R. K., \& Springer, P. (2000). Gifted and nongifted middle school students: Are their attitudes toward school different as measured by the new affective instrument, my class activities, Journal for the Education of the Gifted, 24(1), 74-96.

[17] Hargreaves, M., Homer, M., \& Swinnerton, B. (2008). A Comparison of Performance and Attitudes in Mathematics amongst the Gifted. Are Boys Better At Mathematics or Do They Just Think They Are? Assessment in Education: Principles, Policy \& Practice, 15, 1, $19-38$.

[18] Hizl1, E. (2013). Review of mathematical attitudes of gifted and talented children in terms of various variables, Unpublished Master Thesis, Istanbul University, Istanbul, Turkey.

[19] Hyde, J. S., Fennema, E., Ryan, M., Frost, L. A., \& Hopp, C. (1990). Gender comparisons of mathematics attitudes and affect: A Meta-Analysis, Psychology of Women Quarterly, 14, 299324.

[20] Kalın, G. (2010). The examination of Elementary Studets' Mathematics Attitudes, Self Efficiancy, Anxiety and Achievement, Master Thesis, Ankara, Turkey.

[21] Kanl1, E. (2011). Accelerating gifted and talented in field education, HAYEF: Journal of Education, 16(2), 85-104.

[22] Karasar, N. (2005). Scientific research method, Ankara: Nobel Publications.

[23] Karnes. F.A. \& Wherry, J.N. (1981). Self-concepts of gifted students as measured by the PiersHarris Children's Self-Concept Scale, Psychological Reports, 49(3), 9-14.

[24] Korkmaz, H. \& Kaptan, F. (2002). The effects of project-based learning on elementary school students'academic achievement, academic self concepts and study time in science education. Hacettepe University Education Faculty Journal, 22, 91-97.

[25] Kuloğlu, S. \& Uzel, D. (2013). The analysis of gifted students'mathematical attitudes according to different variables: Manisa Science and Art Center example, Journal of Gifted Education Research, 1(2), Special Issue, 97-107.

[26] Lopez, F. G., Lent, R. W., Brown, S. D., \& Gore, P. A. (1997). Role of social-cognitive expectations in high school students'mathematics-related interest and performance, Journal of Counseling Psychology, 44(1), 44-52.

[27] Marsh, H. W. (1987). The big-fish-little-pond effect on academic self concept, Journal of Educational Psychology, 79(3), 280-295.

[28] Marsh, H. W. \& Craven, R. G. (2006). Reciprocal effects of self-concept and performance from a multidimensional perspective: Beyond seductive pleasure and unidimensional perspectives, Perspectives on Psychological Science, 1(2), 133-163.

[29] Marsh, H. W., Trautwein, U., Lüdtke, O., Köller, O., \& Baumert, J. (2006). Integration of multidimensional self-concept and core personality constructs: Construct validation and relations to well-being and achievement, Journal of Personality, 74, 403-455.

[30] Marsh, H. W. \& O'Mara, A. (2008). Reciprocal effects between academic self-concept, selfesteem, achievement, and attainment over seven adolescent years: Unidimensional and multidimensional perspectives of self-concept, Personality and Social Psychology Bulletin, 34(4), $542-552$. 
[31] Mcclure, L. \& Piggott, J. (2007). Meeting the needs of your most able pupils: Mathematics, London: Routledge.

[32] Metin, N. \& Kangal, S.B. (2012). An Examination of the self concept of 12 to 14 year-old gifted children enrolled in Science and Art Centers, Education and Science, Vol. 37, No 163, 3-16.

[33] Miller, R. C. (1990). Discovering mathematical talent, ERIC EC Digest E482, ED /321487.

[34] Özden, Y. (2003). Learning and Teaching, Ankara: Pegem A Publications.

[35] Pehlivan, H. \& Köseoğlu, P. (2011). Attitudes towards mathematics course and the academic self concept of the students attending At Ankara Science High School, Buca Faculty of Education Journal, 31, 153-167.

[36] Piyanc1, B. (2007). The relationship between the sixth graders self concept related to the computer course and their achievement in computer, Unpublished Master Thesis, Dokuz Eylül University, İzmir, Turkey.

[37] Sanchez, F. \& Roda, M. (2003). Relationship between self-concept and academic achievement in primary students, Electronic Journal of Research in Educational Psychology and Psychopedagogy, 1(1), 95-120.

[38] Schneider, H., Clegg M. R., Byrne B.M., Ledingham J. E., \& Crombie G. (1989). Social relations of gifted children as a function of age and school program, Journal of Educational Psychology, 81(1), 48-56.

[39] Senemoğlu, N. (1989). The Power of Predicting Learning Levels in Mathematics Classes of Student Input Qualifications and Teaching-Learning Process Characteristics (Research Report), Ankara: University of Hacettepe.

[40] Senemoğlu, N. (2007). Developmental learning and teaching from theory to practice, Ankara: Gönül Publications.

[41] Senemoğlu, N. (2010). Developmental learning and teaching from theory to practice, Ankara: Pegem Akademi Publications.

[42] Shavelson, R. J. \& Bolus, R. (1982). Self-concept: The interplay of theory and methods, Journal of Educational Psychology, 74(1), 3-17.

[43] Shechtman, Z \& Silektor, A. (2012). Social competencies and difficulties of gifted children compared to nongifted peers, Roeper Review, 34:1, 63-72.

[44] Sheffield, L.J. (2003). Extending the challenge in mathematics developing mathematical. Promise in K-8 students, California: Corwin Press, Inc.

[45] Sherman, H. J. \& Christian, M. (1999). Mathematics attitudes and global self-concept: An investigation of the relationship, College Student Journal, 33-1, 95-101.

[46] Swetman, D. L. (1991). Fourth grade math: The beginning of the end? Joumal of Reading Improvement, 94, 3, 173-176.

[47] Silverman, L. K. (1992). How parents can support gifted children, ERIC ECDigest \#E515. http://www.nagc.org/index.aspx?id=144

[48] Swiatek, M. A. (2000). Social coping among gifted high school students and its relationship to self consept, Journal of Outcome Measurement, 4 (4), 19-39.

[49] Şenol, C. (2011). Views of teachers about gifted curriculum (Case of BILSEM). University of Firat, Master Thesis, Elazı̆g, Turkey.

[50] Tekbaş, D. \& Ataman, A. (2004). A case study on the enrichment program applied to the gifted child in the inclusion environment and a study on the effectiveness of the program, I. Turkey Gifted Conference Proceedings, 187-200, Istanbul: Children's Foundation Publications. 
[51] Valentine, J., DuBois, D., \& Cooper, H. (2004). The relation between self-beliefs and academic achievement: A meta-analytic review, Educational Psychologist, 111-133.

[52] Weinburg. M. (1995). Gender differences in students'attitutes toward science: A Meta-Analysis of the literature from 1970 to 1991, Journal of Reseach in Science Teaching, 32(4), 387-398.

[53] Yanpar, T. (2005). Variables examining the students'portfolios in the generative approach in the social sciences course, Kastamonu Education Journal, 13, 513-526.

[54] Yenilmez, K. \& Duman, A. (2008). Students'opinions about the factors which affect the mathematics success in elementary education, Journal of Social Sciences, 19, 251-268.

[55] Y1lmaz Atik, Ş. (2007). The evaluation of the methods applied on gifted students in elemetary school, Unpublished Master Thesis, Dokuz Eylül University, Izmir, Turkey.

[56] Yürük, A. (2003). Comparison of self confidences of talented primary school students with students showing normal growth, Unpublished Master Thesis, Hacettepe University, Ankara, Turkey.

[57] Zimmerman, B. J., Bandura, A., \& Martinez-Pons, M. (1992). Self-motivation for academic attainment: The role of self-efficacy beliefs and personal goal setting, American Educational Research Journal, 29, 663-676.

\section{Authors}

Yasemin Deringöl, Istanbul University-Cerrahpaşa, Hasan Ali Yücel Education Faculty, Department of Elementary Education-Primary Education, Istanbul, Turkey, e-mail: dyasemin@istanbul.edu.tr yderingl@gmail.com

\section{Acknowledgement}

This work was supported by Scientific Research Project Coordination Unit of Istanbul University. Project Number: BEK-53985.

This research is an extension of the report presented at the ERPA International Congresses on Education (ERPA-2015). 
